\title{
Microtubular Colorectal Adenoma an Aggressive Histologic Phenotype with Propensity to Evolve into Invasive Carcinoma
}

\author{
Carlos A Rubio $^{1 *}$, Lorand Kis ${ }^{1}$, Denis Nastic ${ }^{1}$, Peter T Schmidt ${ }^{2}$ \\ ${ }^{I}$ Department of Pathology, Center for Digestive Disease Karolinska Institute and University Hospital, \\ Stockholm, Sweden \\ ${ }^{2}$ Department of Medicine, Center for Digestive DiseaseKarolinska Institute and University Hospital, Stockholm, \\ Sweden
}

*Corresponding Author: Carlos A Rubio, Department of Pathology, Center for Digestive Disease Karolinska Institute and University Hospital, Stockholm, Sweden, Email: Carlos.Rubio@ki.se

\begin{abstract}
Colorectal carcinoma, the third most commonly diagnosed type of cancer in Europe and the USA, usually originates in colorectal adenomas (CRA). Two main histological phenotypes of CRA are usually recognized: conventional (tubular or villous) adenomas and traditional serrated (serrated and microtubular) adenomas. Microtubular adenomas (MTA) are histologically typified by dysplastic epithelium arranged in closed rings (microtubules), sideways along elongated outgrowth. We investigated 4446 CRA diagnosed at this Department during a 10-year period (2001-2010). Out of the 4446 CRA, 68 (1.5\%) were MTA; of these, 38 (55.9\%) had low-grade dysplasia (LGD), 17 (25.0\%) high-grade-dysplasia (HGD), two (2.9\%) intraepithelial carcinoma (IEC), three (4.4\%) intramucosal carcinoma (IMC), and eight (11.8\%) submucosal carcinoma (SMC). Ninety-four per cent (64/68) of the MTAs were left-sided adenomas. Cell proliferation in MTA occurred initially in the dysplastic microtubules. In contrast, cell proliferation occurred initially at the luminal aspect of the dysplastic crypts in conventional (tubular or villous) adenomas, and initially at the bottom of the dysplastic crypts in serrated adenomas. Because of distinctive microscopic characteristics, and cell proliferative attributes, it is submitted that MTA is a particular CRA phenotype, at variance with conventional (tubular or villous) adenomas and serrated adenomas. The high frequency of submucosal invasion strongly suggests that MTA is an aggressive phenotype of CRA.
\end{abstract}

Keywords: Advanced adenomas, microtubular configurations, invasive carcinoma

\section{INTRODUCTION}

Colorectal carcinoma (CRC) is the third most commonly diagnosed type of cancer in Europe and the USA [1]. Main risk factors include advanced age, family history, male sex, lifestyle factors natural exposures to dietary/environmental factors, genome differences, obesity, type 2 diabetes, and the colonic microbiome [2]. CRC usually originates in mucosal foci of mutated cells with proliferative, biochemical and molecular aberrations, referred to as colorectal adenomas (CRA)[3].Less frequently, CRC develops from dysplastic crypts in flat mucosa in patients with ulcerative colitis[4], from epithelial cells covering gut-associated lymphoid tissue [5],or from mucosa without any recognizable preceding dysplastic alteration (de novo carcinoma) $[6,7]$.

CRA have been classically classified into conventional (tubular or villous) adenomas
(CTVA) [8], and serrated (SA) adenomas (typified by dysplastic, teeth-like outlines that resemble serrations in a saw) [9].

In 1997, we found in Japanese patients a CRA that was at variance with the aforementioned histological phenotypes, as it displayed closed dysplastic microtubules arranged in a sequential fashion along the slopes of epithelial outgrowths [10]. Initially called villo-microglandular adenoma it was later re-named microtubular adenoma (MTA) by the WHO in 2000 [11]. Since its description in Japanese patients, MTAs were also reported in Swedish [3], Italian [12], English [6] and Icelander [13] patients. MTA and SA are being referred to as traditional serrated adenoma (TSA) [14, 13].

Based on the degree of cellular dysplasia, some authors have classified CRA into those exhibiting slight, moderate or severe dysplasia [15], and others showing low and high-grade dysplasia (LGD and HGD, respectively)[16]. 
More recently, the concept of advanced CRA (ACRC) [17] has received wide acceptance due to its propensity to progress to invasive carcinoma [18, 19]. It should be pointed out, however, that the definition of ACRC varies in the literature. Some authors regard as ACRC those adenomas measuring $>1 \mathrm{~cm}$ in diameter $[20,21]$, others $>1 \mathrm{~cm}$ in diameter with villous histology [22-24]; others require the presence of HGD [25-27]; others, at least $1 \mathrm{~cm}$ or with villous elements at a frequency greater than $20 \%$ or with HGD [28]; and others as carcinoma in situ (intraepithelial carcinoma, IEC)[29-31] Finally, some authors require the presence of in tramucosal carcinoma (IMC) [19, 32-34].

In early work, we investigated 92 consecutive CRAs with submucosal carcinoma (SMC) having HGD or IEC in the remnant adenomatous tissue[35].Although submucosal invasion occurred more frequently in CRA with IEC than in those with HGD, as many as $42 \%$ of the SMCs arose in CRA with HGD exclusively. Despite morphological, histochemical and immunohistochemical dissimilarities between the two lesions [35-37] it was concluded that both HGD and IEC have a particular propensity to invade host tissue.

The purpose of the present work was to assess the frequency of MTA in a cohort of CRAs diagnosed between 2001 and 2010 at this Department.

\section{Material AND MethodS}

The material comprised 4446 polypectomies exhibiting CRA at histology, diagnosed at the Department of Pathology, Karolinska University Hospital during a 10-year period (2001-2010). A total of 3456 CRAs were diagnosed by the author (CR); and the remaining 990 CRAs by other pathologists at the Department. Sections from these 990 CRA were retrieved from the files and reviewed; the aim was to detect possible unreported cases of MTA.

Conventional (tubular and villous) adenomas, SA and sessile serrated polyp/adenoma (SSA/P) were excluded from the study.

\section{Definitions}

MTA: CRA exhibiting closed rings (microtubules) of dysplastic epithelium arranged lengthwise along the slopes of elongated out growths present in $>50 \%$ of the adenomatous tissue (Figure 1).

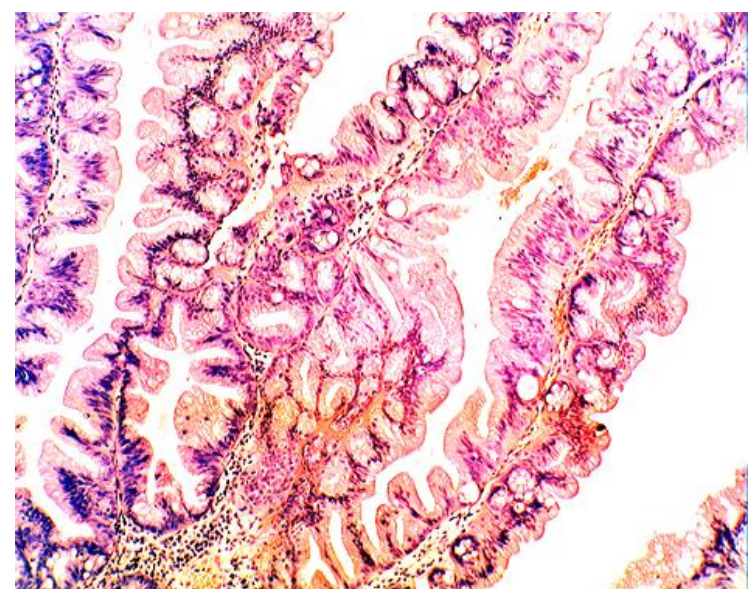

Figure1. Microtubular adenoma showing sideways dysplastic microtubules ( $H \& E, X 4)$.

Classification of MTA according to the degree of neoplastic severity

i) LGD: Dysplastic epithelium lined with spindle-shaped, rather uniform hyperchromatic nuclei, with regular nuclear membrane. Chromatin particles are uniformly small and the stratified nuclei do not exceed the deeper half of the epithelial thickness.

ii) HGD: Dysplastic epithelium lined with spindle-shaped cells with hyperchromatic, pleomorphic nuclei. Chromatin particles are irregular with angular shapes, and the nuclear membrane is regular. Stratified nuclei exceed the superficial half of the epithelium often reaching< the luminal epithelial border. Atypical mitoses are often present (Figure 2).

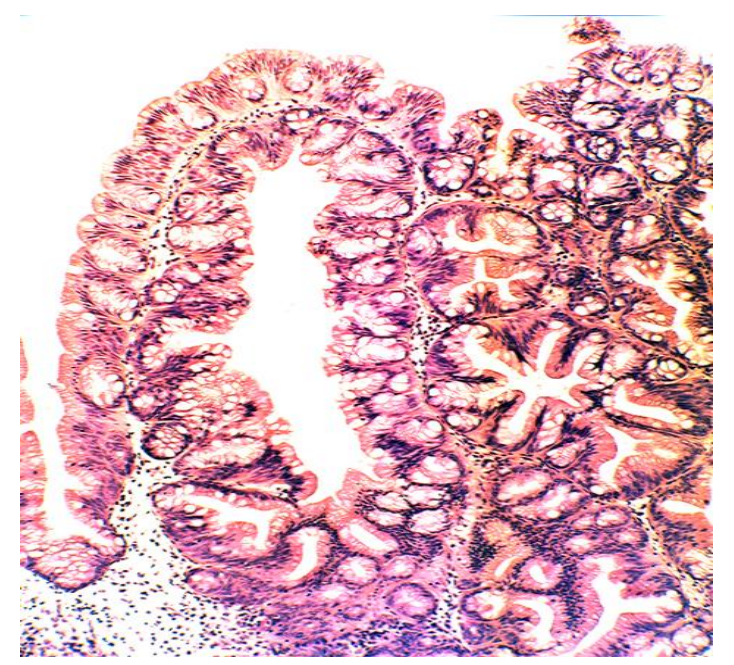

Figure2. Another microtubular adenoma showing sideways dysplastic microtubules (H\&E4) 
iii) IEC: Intraepithelialneoplastic epithelium exhibiting marked pleomorphic cells with swollen large vesicular (oval or roundshaped) nuclei, with bridges of nucleolusassociated chromatin reaching angular chromatin deposits both in the nucleus and on the nuclear membrane. Nucleolus is conspicuous $(\geq 2.5 \mu \mathrm{m}$ in diameter) and irregular and the nuclear membrane is often notched. The nuclear polarity is disrupted and atypical mitoses are found. Structural glandular alterations consist of budding or branching crypts or tubules with epithelial septa, back-to-back glands and cribriform growth. The glands are often arrayed obliquely to the basement membrane (Figure 3).

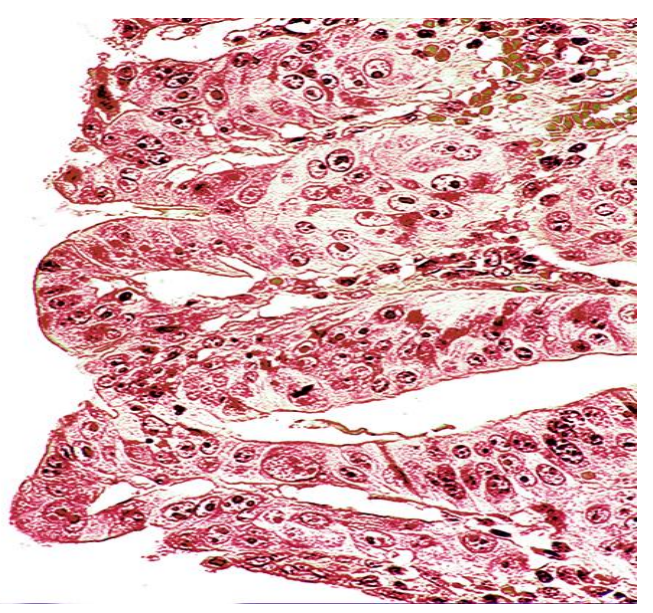

Figure3. Microtubular adenoma with high-grade dysplaia. Notelarge pleomorphic, pale vesicular nuclei with large, prominent, irregular nucleoli $(H \& E, X 40)$.

iv) $I M C$ : Adenomawith neoplastic cells with unquestionable invasion into the lamina propria mucosae. A desmoplastic reaction in the juxtaposing lamina propriaand/or a neutrophilic infiltration occurred at the site of invasion (Figure 4).

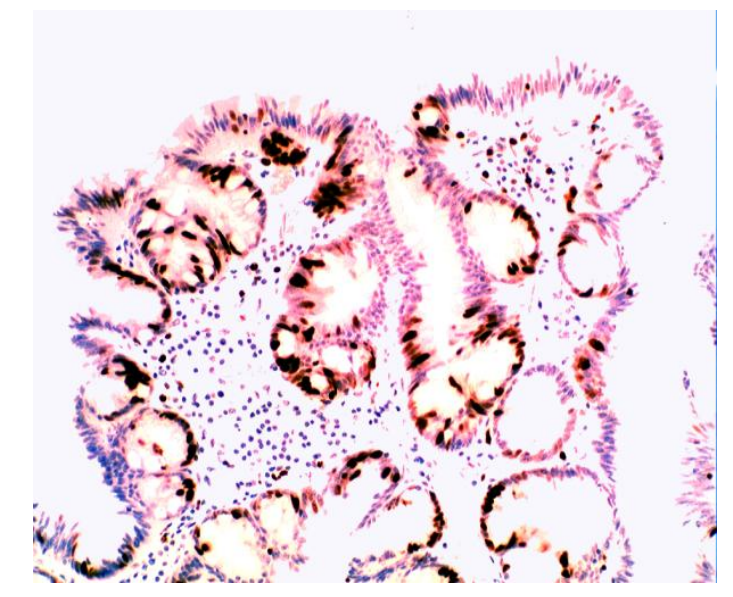

Figure4. Microtubular adenoma immunostained with reveling that cell proliferation initially occurs in microtubules (Ki67, batch MIB1 x20)

v) SMC: Adenoma with neoplastic cells invading across the muscularis mucosae and unquestionably reaching the submucosal layer (Figure 5).

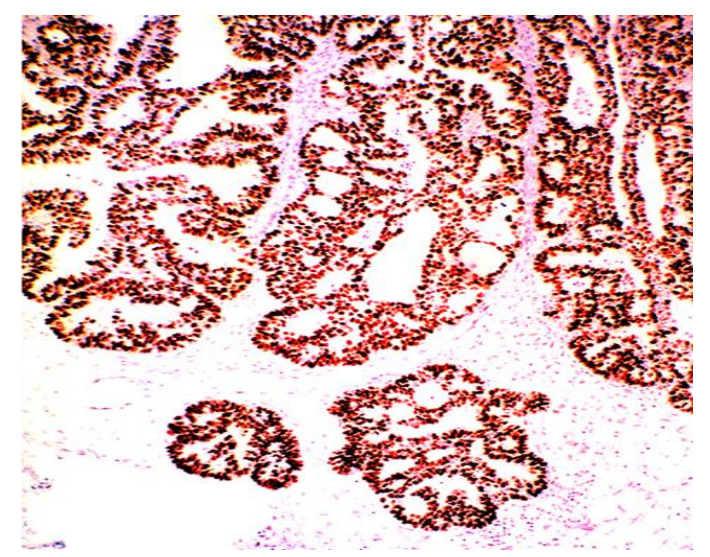

Figure5. Invasive carcinoma evolving from microtubular adenoma.

Note that the invading tumour retains the microtubular features (p53, X4).

Statistical analysis. The non-parametric KruskalWallis test was applied, to compare difference between groups. Statistical significance was defined as $\mathrm{P}<0.05$.

This study was approved by the Ethics Committee, Department of Pathology, Karolinska University Hospital.

\section{Results}

Out of 68 MTAs, 37 (54\%) were found in males and the remaining $31(46 \%)$ in females. The mean age of patients with MTA was 59 years (range $=25-82$ years); $25(37 \%)$ were $\leq 59$ years of age and the remaining 43 (63\%), $\geq 60$ years of age.

Of the 68 MTA, 64 (94.1\%) were located in the left colon-rectum and the remaining four $(5.9 \%)$ in the right colon $(p<0.05)$.

Histological Evaluation. Out of the 3456 CRAs reviewed by CR, $58(1.7 \%)$ were MTA. The review of the remaining 990 CRAs diagnosed by other pathologists at the Department revealed that 10 CRAs initially diagnosed as TA $(n=2)$, VA $(n=5)$, or SA $(n=3)$ were MTA at review. Hence, MTA accounted for $1.5 \%(\mathrm{n}=68)$ of all CRAs $(n=4446)$ seen at this Department between 2001 and 2010. Out of 68 MTAs, $55.9 \%$ had LGD, 25.0\% HGD, 2.9\% IEC, $4.4 \%$ IMCs and the remaining $11.8 \%$ SMCs. 


\section{DISCUSSION}

In this survey, MTA accounted for $1.5 \%$ of 4446 CRA; of those, histology showed LGD in $55.9 \%$, HGD in $25.0 \%$, IEC in $2.9 \%$, IMC in $4.4 \%$ and SMC in the remaining $11.8 \%$. These results validate previous results obtained in 1552 CRA in Florence, Italy [12] where 35.7\% of the MTAs had HGD, IEC and IMCs; SMC were recorded in $7.1 \%$. Accordingly, previous and present findings strongly indicate that MTAs are aggressive lesions, with propensity to evolve into invasive carcinoma.

Fifty-four percent of the patients with MTA were males, and $63 \%$ were $\geq 60$ years of age. These percentages are similar to those recorded in a cohort of Swedish patients with CRA where all phenotypes of CRA were investigated [3]. In that work, $52 \%$ of 3135 CRAs were males and $65 \%$ were $\geq 60$ years of age. It would appear that the development of MTA is neither influenced by the gender nor by the age of the patients.

The degree of cellular dysplasia and invasion into the lamina propriaor into the submucosa were separately analysed. This was done since progression of cellular neoplastic aberrations requires accumulation of genetic cell mutations [38], whereas penetration of the basement membrane by neoplastic cells requires collagendegrading proteolytic enzymes, such as collagenase, plasminogen activator [39], heparanase [40], and matrilysin [41].

In 2008, Torlakovicet al. noted morphological features in TSA, such as filiform projections andectopic crypt formations [14]. The criteria and illustrations in TSA with ectopic crypt formations in that publication are identical to those previously reported for MTA in Japanese patients in 1997 [10], endorsed by the WHO in 2000 [11], and subsequently in Swedish patients in 2002 [3], in Italian patients in 2003 [12] and in English patients in 2007 [6]. We prefer the descriptive term microtubular to 'ECF' [14], in as much as microtubular configurations are also present in invasive areas [42].

Since the age of the patients was similar in MTA to other adenoma phenotypes, there was no indication that TA, VA or SA had chronologically 're-modelled' into MTA, or that MTA, TA, VA and SA were transitional patterns capable of converting into a different phenotype with increasing age.

In previous work we found that cellproliferation occurred initially in the dysplastic microtubules of MTA, initially in the luminal dysplastic epithelium in CTVA initially, and initially at the bottom of the crypts in SA [4, 4244]. Because of the distinctive microscopic and cell proliferative attributes, it is submitted that MTA is as a specific CRA phenotype, at variance with TA, VA, and SA. The high frequency of SMC strongly suggests that MTA is an aggressive phenotype of CRA.

\section{REFERENCES}

[1] Ferlay J, Steliarova-Foucher E, Lortet-Tieulent J, Rosso S, CoeberghJW, Comber H, Forman D,Bray FCancer incidence and mortality patterns in Europe: Estimates for 40 countries in 2012.Eur J Cancer 2013; 49:1374-1403.

[2] Rabeneck L, Horton S, Zauber AG, et al. Colorectal Cancer In: Gelband H, Jha P, Sankaranarayanan R, Horton S, editors. Cancer: Disease control priorities. Third Edition. Washington (DC): The International Bank for Reconstruction and Development. The World Bank; 2015; 1 .

[3] Rubio CA Colorectal adenomas: Time for reappraisal. Pathol Res Pract 198: 615-620, 2002.

[4] Lennard-Jones JE, Melville DM, Morson BC, Ritchie JK and Williams CB: Precancer and cancer in extensive ulcerative colitis: Findings among 401 patients over 22 years. Gut 31: 800806, 2002.

[5] Rubio CA, Puppa G, de Petris G, Kis L, Schmidt P. The third pathway of colorectal carcinogenesis. JClin Pathol, 2018, 71: 7-11.

[6] Rubio CASerrated neoplasias and de novo carcinomas in ulcerative colitis: a histological study in colectomy specimens. JGastroenterolHepatol. 2007; 22:1024-1031.

[7] HornickJL, Farraye FA, Odze RD.Clinicopathologic and immunohistochemical study of small apparently "de novo" colorectal adenocarcinomas.Am J SurgPathol. 2007; 31:207215.

[8] Atkin WS and Saunders BPSurveillance guidelines after removal of colorectal adenomatous polyps. Gut 2002; 51Suppl 5: V6-9,

[9] Longacre TA, Fenoglio-Preiser CMMixed hyperplastic adenomatous polyps/serrated adenomas. A distinct form of colorectal neoplasia. Am J SurgPathol 1990;14: 524-537.

[10] Kubo K, Kato Y, Yanagisawa A. Rubio CA, Hiratsuka HSerrated colorectal adenomas. Endosc Digest 1997; 9: 559-563,.

[11] Hamilton S, Vogelstein B, Kudo S, Riboli E, Nakamura S, Hainaut P, Rubio CA, Sobin LH, Fogt F, Winawer SJ, Goldgar D, Jass JR Carcinoma of the colon and rectum. In: World 
Health Organization Classification of Tumours of the Digestive System. Pathology \& Genetics. Tumours of the Digestive System. Ed Stanley R Hamilton and Lauri A Aaltonen. Lyon: IARC Press, pp. 104-119, 2000.

[12] Rubio CA, NesiG, Kato YSerrated and microtubular adenomas of the colon and rectum. An 8-year histological survey. Anticancer Res2003; 23: 1693-1696.

[13] Rubio CA, Jónasson JGTwo Phenotypes of TraditionalSerratedAdenomas Nationwide Survey in Iceland. Anticancer Res 2015; 35:4929-33

[14] Torlacovich EE, Gomez JD, Driman DK Sessile serrated adenoma (SSA) vs. traditional serrated adenoma (TSA). Amer J Surgic Patholol 2008; 32: 21-29.

[15] O’Brien MJ, WinawerSJ, Zauber AG, Gottlieb LS, SternbergSS, Diaz B, Dickersin GR, Ewing S, Geller S, Kasimian D, National Polyp Study Workgroup: Patient and polyp characteristics associated with high-grade dysplasia in colorectaladenomas. Gastroenterology 1990; 98: 371-379.

[16] Adachi M, Ryan P, Collopy B, Fink R, Mackay J, Woods R,Okinaga K, Muto T, Moriaka Y Adenoma-carcinomasequence of the large bowel. Aust NZ J Surg 1991; 61: 409-414.

[17] Gschwantler M, Kriwanek S, Langner E, G.ritzer B, Schrutka- C, Brownstone E, Feichtinger H, Weiss W High-gradedysplasia and invasive carcinoma in colorectal adenomas: Amultivariate analysis of the impact of adenoma and patientcharacteristics. Eur $\mathbf{J}$ GastroenterolHepatol2002; 14: 183-188.

[18] O'Brien MJ, Gibbons DThe adenomacarcinoma sequencein colorectal neoplasia. SurgOncolClin N Am 1996; 5: 513-530.

[19] Rubio CA, Kristjansdottir S, Thodleifsson B, Olafsdottir E, Jonasson JG The frequency of advanced adenoma in consultingpatients: A nationwide survey in Iceland (2003-2006). ColorectalDis 2012; 14: 595-602.

[20] Jörgensen OD, Kronborg O, Fenger $\mathrm{C}$ and Rasmussen M:Influence of long-term colonoscopic surveillance on incidenceof colorectal cancer and death from the disease in patients withprecursors (adenomas). ActaOncol 46: 355-360, 2007.

[21] Ishii T, Notohara K, Umapathy A, Mallitt KA, Chikuba H,Moritani Y, Tanaka N, Rosty C, Matsubara N, Jass J, Leggett B, Whitehall V: Tubular adenomas with minor villous changesshow molecular features characteristic of tubulovillousadenomas. Am J SurgPathol 35: 212-220, 2011.

[22] Bonithon-Kopp C, Piard F, Fenger C, Cabeza E, O'Morain C,Kronborg $\mathrm{O}$ and Faivre
JEuropean Cancer Prevention Organisation Study Group. Colorectal adenoma characteristics as predictors of recurrence. Dis Colon Rectum 2004; 47: 323-333.

[23] Cordero C, Leo E,Cayuela A, Bozada JM, Garc.a E, PizarroMAValidity of early colonoscopy for the treatment ofadenomas missed by initial endoscopic examination. Rev EspEnfermDig 2001; 93: 519-528.

[24] Martínez ME, Sampliner R, Marshall JR, Bhattacharyya AK,Reid ME, and Alberts DS: Adenoma characteristics as riskfactors for recurrence of advanced adenomas. Gastroenterology 120: 1077-1083, 2001.

[25] Nusko G, Hahn EG, MansmannU Risk of advancedmetachronous colorectal adenoma during long-term follow-up.Int J Colorectal Dis 2008; 23: 1065-1071.

[26] Wong HL, Peters U, Hayes RB, Huang WY, Schatzkin A,Bresalier RS, Velie EM, Brody LCPolymorphisms in theadenomatous polyposis coli (APC) gene and advanced colorectaladenoma risk. Eur J Cancer 2010; 46: 2457-2466.

[27] WinawerSJ, Zauber AG, Fletcher RH, StillmanJS, O'brien MJ,Levin B, Smith RA, Lieberman DA, Burt RW, Levin TR, BondJH, Brooks D, Byers T, Hyman N, Kirk L, Thorson A, SimmangC, Johnson D, Rex DKGuidelines for colonoscopysurveillance after polypectomy: a consensus update by the USMulti-Society Task Force on Colorectal Cancer and theAmerican Cancer Society. CA Cancer J Clin2006; 56: 143-159.

[28] Denis B, Peters C, Chapelain C, Kleinclaus I, Fricker A, WildR, Aug. B, Gendre I, Perrin P, Chatelain D, Fl.jouJFDiagnostic accuracy of community pathologists in theinterpretation of colorectal polyps. Eur J GastroenterolHepatol 2009; 21: 1153-1160.

[29] Noshirwani KC, van Stolk RU, Rybicki LA, Beck GJAdenoma size and number are predictive of adenoma recurrence:implications for surveillance colonoscopy. Gastrointest Endosc 2000; 51: 433-437.

[30] Yamaji Y, Mitsushima T, Ikuma H, Watabe H, Okamoto M,Kawabe T, Wada R, Doi H, OmataM Incidence andrecurrence rates of colorectal adenomas estimated by annuallyrepeated colonoscopies on asymptomatic Japanese. Gut 2004; 53: 568572.

[31] Wark PA, Wu K, van 't Veer P, Fuchs CF, Giovannucci ELFamily history of colorectal cancer: A determinant of advancedadenoma stage or adenoma multiplicity? Int $\mathrm{J}$ Cancer 2009; 125: 413-420.

[32] Terry MB, Neugut AI, Bostick RM, Potter JD, Haile RW, Fenoglio-Preiser CM: Reliability in 
the Classification ofAdvanced Colorectal Adenomas. Cancer Epidemiol BiomarkersPrev 2002; 11: 660-603.

[33] Chaput U, Alberto SF, Terris B, Beuvon F, Audureau E, CoriatR, Roche H, Gaudric M, Prat F,ChaussadeS Risk factorsfor advanced adenomas amongst small and diminutive colorectalpolyps: A prospective monocenter study. Digest Liver Dis 2011; 43:609-612.

[34] Lakis S, Papamitsou T, Panagiotopoulou C, Kotakidou R, Kotoula V: AMACR is associated with advanced pathologic riskfactors in sporadic colorectal adenomas. World Gastroenterol2010; 16: 2476-2483.

[35] Rubio CA, Delinassios JG Invasive carcinomas may arise incolorectal adenomas with highgrade dysplasia and with carcinoma in situ. Int J ClinExp Med 2010; 3: 41-47.

[36] Rubio CA: Qualitative DNA differences between two structurally different lesions: High-grade dysplasia and carcinoma in situ in colorectal adenomas. Anticancer Res 27: 2881-2885.

[37] Rubio CA: Difference in cell proliferation between twostructurally different lesions in colorectal adenomas: high-gradedysplasia and carcinoma in situ. Anticancer Res 2007; 27: 4321-4324.

[38] Vogelstein B, Fearon ER, Hamilton SR, Kern SE, Preisinger AC, Leppert M, Nakamura Y, White R, Smits AM, BosJL: Genetic alterations during colorectal-tumor development. N EnglJ Med 1988; 319: 525-528.
[39] Salo T, Liotta LA, Keski-Oja J, TurpeenniemiHujanen T, Tryggvason $\mathrm{K}$ Secretion of basement membrane collagen degrading enzyme and plasminogen activator by transformed, cells-role in metastasis. Int $\mathbf{J}$ Cancer 1982; 30: 669-673.

[40] Xie ZJ, Liu Y, Jia LM, He YCH eparanase expression, degradation of basement membrane and low degree of infiltration by immunocytes correlate with invasion and progression of human gastric cancer. World J Gastroenterol2008; 14:3812-3818.

[41] Masaki T, Matsuoka H, Sugiyama M, Abe N, Goto A, Sakamoto, A, Atomi Y: Matrilysin (MMP-7) as a significant determinant of malignant potential of early invasive colorectal carcinomas.Br J Cancer 2001; 84: 1317-1321.

[42] Rubio CA, Jaramillo E Advanced microtubular colorectal adenomas: a 10-year survey at a single hospital. Anticancer Res. 2013; 33:54715476.

[43] Rubio CA, Rodensjo M Flat serrated adenomas and flat tubular adenomas of the colorectal mucosa: ifferences in the pattern of cell proliferation. Jpn J Cancer Res 1995; 86: 756760.

[44] Rubio CA, Slezak P. The unique pathology of nonpolypoid colorectal neoplasia in IBD. GastrointestEndoscClin N Am 2014; 24:45568.

Citation: Carlos A Rubio, Lorand Kis, Denis Nastic, Peter T Schmidt. Microtubular Colorectal Adenoma an Aggressive Histologic Phenotype with Propensity to Evolve into Invasive Carcinoma. ARC Journal of Cancer Science 2017; 3(2):31-36. DOI: http://dx.doi.org/10.20431/2455-6009.0302005

Copyright: (c) 2017 Authors. This is an open-access article distributed under the terms of the Creative Commons Attribution License, which permits unrestricted use, distribution, and reproduction in any medium, provided the original author and source are credited. 